\title{
KEPUASAN PASIEN STROKE PESERTA JKN DI RS LESTARI RAHARJA DAN RSUD MUNTILAN KABUPATEN MAGELANG
}

\author{
Eka Ari Wibawa1 ${ }^{1}$ Tjahjono Kuntjoro ${ }^{2}$, Rizaldy Taslim Pinzon ${ }^{3}$ \\ ${ }^{1}$ Pasca Sarjana Fakultas Kedokteran Universitas Gadjah Mada \\ ${ }^{2}$ Presiden Direktur Rumah Sakit Ken Saras Semarang Jawa Tengah \\ ${ }^{3}$ Fakultas Kedokteran Universitas Kristen Duta Wacana
}

Korespondensi: drpinzon17@gmail.com

\begin{abstract}
ABSTRAK
Latar Belakang: Stroke merupakan penyebab kematian nomor tiga, setelah penyakit jantung dan kanker. Stroke juga merupakan penyebab utama kecacatan fisik maupun mental pada usia lanjut dan produktif. Jumlah penderita stroke di Indonesia semakin bertambah dan diderita oleh semua lapisan masyarakat. Keadaan tersebut harus mendapatkan perhatian, sehingga penanganan penderita stroke diharapkan dilakukan dengan suatu standar yang pasti. Pelayanan yang dilakukan dengan standar akan menghasilkan mutu pelayanan rumah sakit yang dapat dipertanggungjawabkan dan pada akhirnya memunculkan kepuasan pasien.

Tujuan: Tujuan dari penelitian ini adalah membandingkan kepuasan pasien penderita stroke peserta Jaminan Kesehatan Nasional (JKN) terhadap mutu pelayanan RS Lestari Raharja Magelang dan RSUD Muntilan Kabupaten Magelang.

Metode: Penelitian ini merupakan penelitian relational, dengan disain penelitian kombinasi model concurrent embedded. Instrumen yang digunakan dalam penelitian ini adalah menggunakan kusioner tertutup yang telah dipakai oleh peneliti sebelumnya dan pedoman wawancara yang disusun semi struktural, yaitu berupa pertanyaan-pertanyaan yang digunakan untuk mendapatkan informasi lebih mendalam tentang faktor kepuasan pasien secara umum maupun berdasarkan 5 aspek; penampilan fisik, kemampuan pelayanan yang akurat, daya tanggap, jaminan dan empati kepada pasien/ keluarga pasien penderita stroke di rumah sakit.

Hasil: Hasil penelitian menunjukkan bahwa $82,4 \%$ pasien penderita stroke di RSUD Muntilan Kabupaten Magelang dan 74,2\% pasien penderita stroke di RS Lestari Raharja yang merupakan peserta JKN menyatakan puas terhadap pelayanan rumah sakit. Hasil analisa bivariat hubungan jenis rumah sakit terhadap kepuasan pasien menunjukkan tidak ada hubungan yang signifikan (OR $1,63,95 \% C I 0,51-4,90$ dan $p$ value 0,33 ). Hasil analisa multivariat pengaruh jenis rumah sakit terhadap kepuasan pasien menunjukkan tidak ada hubungan yang signifikan antara jenis rumah sakit terhadap kepuasan pasien $(O R$ 1,38, 95\%CI 0,36-5,28 dan $p$ value 0,63).

Kesimpulan: Penelitian ini menunjukkan tidak ada perbedaan kepuasan pasien penderita stroke yang dirawat di RS Lestari Raharja dan RSUD Muntilan Kabupaten Magelang serta tidak ada hubungan antara jenis rumah sakit terhadap kepuasan pasien.
\end{abstract}

Kata Kunci: Kepuasan pasien, stroke, jaminan universal. 


\title{
SATISFACTION OF STROKE PATIENTS THE NATIONAL HEALTH INSURANCE (JKN) IN THE LESTARI RAHARJA HOSPITAL AND MUNTILAN HOSPITAL (MAGELANG DISTRIC HOSPITAL)
}

\author{
Eka Ari Wibawa1 ${ }^{1}$ Tjahjono Kuntjoro ${ }^{2}$, Rizaldy Taslim Pinzon ${ }^{3}$ \\ ${ }^{1}$ Student of Hospital Management, Faculty of Medicine, Gadjah Mada University \\ ${ }^{2}$ President Director of Ken Saras Hospital Semarang Central Java \\ ${ }^{3}$ Medical Faculty of Duta Wacana Christian University \\ Correspondence: drpinzon17@gmail.com
}

\begin{abstract}
Background: Stroke is the third leading cause of death, after heart disease and cancer. Stroke is also a major cause of physical and mental disabilities in the community. The number of stroke patients in Indonesia is increasing and affects all levels of society. Treatment of patients with stroke should be done with the basic standards to reduce the effects of stroke. Services performed by the standard procedure will produce the quality of hospital services which can be accounted for and eventually led to patient satisfaction.

Objective: To compare the satisfaction of patients with stroke covered by the National Health Insurance (JKN) to the quality of health care in the Lestari Raharja Hospital and Muntilan Hospital (Magelang Distric Hospital).

Methods: The research applied a mixed methods concurrent embedded. The subjects are the stroke patients were hospitalized in the hospital for more than three days in Lestari Raharja Hospital and 74 stroke patients in the Muntilan Hospital (Magelang Distric Hospital).

Results and Discussion: Results showed that $82.4 \%$ of patients with stroke in Muntilan Hospital (Magelang Distric Hospital) and $74.2 \%$ of patients with stroke in the Lestari Raharja Hospital which is a participant JKN satisfied with the services of the hospital. The results of the bivariate analysis of the relationship between hospital type to patient satisfaction showed no significant association (OR 1.63, 95\% CI 0.51 to 4.90 and $p$ value 0.33). The results of the multivariate analysis of the influence between the hospital type to the patient satisfaction showed no significant (OR 1.38, 95\% CI 0.36 to 5.28 and $p$ value 0.63).

Conclusion: This study showed that there are no difference in satisfaction of stroke patients who were treated in the Lestari Raharja Hospital and Muntilan Hospital (Magelang Distric Hospital), and there is no relationship between the type of hospital to the patient's satisfaction.
\end{abstract}

Keywords: Patient satisfaction, stroke, universal coverage. 


\section{PENDAHULUAN}

Stroke adalah suatu gangguan yang terjadi pada pembuluh darah otak dengan serangan akut yang dapat menyebabkan gangguan neurologis dan berlangsung lebih dari 24 jam atau menyebabkan kematian dalam waktu singkat. Stroke merupakan penyebab kematian nomor tiga, setelah penyakit jantung dan kanker serta penyebab utama kecacatan fisik maupun mental pada usia lanjut dan produktif. ${ }^{1}$ Prevalensi stroke di Indonesia pada tahun 2008 ditemukan sebesar $0,83 \%$ penduduk, dan meningkat menjadi $1,21 \%$ penduduk pada tahun 2013.2 Angka tersebut tidak jauh berbeda dengan prevalensi stroke di Yogyakarta dan Jawa Tengah pada tahun 2008 berturut-turut $0,811 \%$ penduduk dan $0,76 \%$ penduduk. $^{2}$

Pinzon, Adnyana \& Sanyasi dalam penelitiannya di RS Bethesda menunjukkan proporsi penderita stroke pada tahun 2011-2013 lebih didominasi oleh jenis kelamin laki-laki $57,60 \%$, sedang pada tahun 2015 meningkat menjadi $58,04 \% .^{3}$ Dilihat dari jenis serangan, stroke iskemik (non haemoragik) paling sering terjadi sebesar $76,75 \%$ pada tahun 20112014 dan pada tahun 2015 sebesar $76,29 \%$. Angka kematian penderita stroke di RS Bethesda tahun 20112014 adalah 8,89\% dan tahun 2015 sebesar 12,27\%, masih lebih rendah dari kematian stroke secara nasional maupun regional.

Peningkatan penderita stroke yang terjadi di semua lapisan masyarakat, memerlukan penanganan yang dilakukan dengan suatu standar yang pasti, untuk mencegah bertambah berat akibat yang ditimbulkannya dan mengurangi kesenjangan dalam pelayanan penderita stroke di berbagai rumah sakit, dengan mengintegrasikan clinical pathway dalam rekam medis pelayanan pasien sehari-hari. ${ }^{4}$
Kepuasan adalah tingkat perasaan seseorang/ pelanggan setelah membandingkan antara hasil yang dirasakan dengan yang diharapkannya, yang menimbulkan perasaan senang atau kecewa, yang dipengaruhi oleh beberapa faktor seperti gaya hidup, tingkat ekonomi dan pendidikan, pengalaman masa lalu, harapan masa depan dan nilainilai individu dan masyarakat. ${ }^{5}$ Faktor utama kepuasan pasien adalah mutu pelayanan kesehatan yang diberikan rumah sakit, yang dapat dinilai dari tiga komponen yaitu; struktur rumah sakit, proses pelayanan dan hasil akhir dari pelayanan. 6,7 Andaleeb menyebutkan terdapat 5 dimensi mutu pelayanan yang perlu diperhatikan, sesuai yang dikembangkan oleh Parasuraman (1985, 1988), dengan model Servqual sebagai berikut; tangibles (bukti fisik), reliability (keandalan), responsiveness (daya tanggap), assurance (jaminan dan kepastian) dan empathy. ${ }^{8}$

Al Khattab \& Aborumman dalam penelitian tentang mutu pelayanan kesehatan yang membandingkan antara rumah sakit swasta dan pemerintah di Jordania terhadap 221 responden menemukan keluhan utama terhadap pelayanan di rumah sakit pemerintah adalah daya tanggap dan empati yang berhubungan dengan kelambatan pelayanan dan singkatnya waktu konsultasi. 9 Penelitian lain juga menyebutkan beberapa pasien merasa lebih puas dengan pelayanan rumah sakit swasta. ${ }^{10,11}$

Peserta Jaminan Kesehatan Nasional (JKN) mendapatkan pelayanan kesehatan rujukan/ lanjutan baik rawat jalan maupun rawat inap di rumah sakit milik pemerintah maupun rumah sakit swasta yang telah bekerja sama dengan Badan Penyelenggara Jaminan Sosial (BPJS). Di Kabupaten Magelang, pelayanan rawat inap penderita stroke peserta JKN dapat 
dilakukan di RSUD Muntilan yang merupakan rumah sakit kelas $\mathrm{C}$ milik Pemerintah Kabupaten Magelang dengan 208 tempat tidur dan RS Lestari Raharja, yang merupakan rumah sakit swasta kelas D dengan 60 tempat tidur. Sarana prasarana maupun pelayanan spesialistik bagi penderita stroke yang diberikan kedua rumah sakit tidak jauh berbeda antara lain; memiliki 1 dokter spesialis syaraf, menerapkan standard operating procedure (SOP) dan clinical pathway serta survei kepuasan pasien menggunakan Indek Kepuasan Masyarakat (IKM) di RSUD Muntilan tahun 2014 mendapatkan hasil ratarata 74, dan di RS Lestari Raharja pada tahun 2013 dengan hasil 76, sehingga asumsinya kedua rumah sakit dalam pelayanan kepada publik masuk dalam kriteria baik dan mutu pelayanan kesehatan yang diberikan juga sama yang akan akhirnya memunculkan kepuasan pasien.

\section{METODE PENELITIAN}

Penelitian ini adalah penelitian relational, dengan disain mixed methods concurrent embedded, untuk membandingkan kepuasan pasien stroke peserta JKN yang dirawat di Rumah Sakit Lestari Raharja dan RSUD Muntilan Kabupaten Magelang. ${ }^{12}$

Subyek pada penelitian kuantitatif ini adalah pasien stroke yang menjalani rawat inap di RSUD Muntilan dan RS Lestari Raharja Magelang. Jumlah sampel pada penelitian kuantitatif berjumlah 105 responden (31 pasien stroke di RS Lestari Raharja dan 74 pasien stroke di RSUD Muntilan). Subyek pada penelitian kualitatif diambil dari responden penelitian kuantitatif dengan jumlah responden sampai terjadi saturasi data.

Peneliti menggunakan tehnik pengumpulan data melalui wawancara. Wawancara pertama menggunakan kuesioner dengan pertanyaan tertutup, dilanjutkan wawancara dengan pedoman wawancara yang disusun semistruktural berdasarkan kuesioner tertutup, yang dilakukan pada periode 15 Februari sampai dengan 30 Mei 2016.

Variabel terikat pada penelitian ini adalah kepuasan pasien stroke terhadap pelayanan rumah sakit, sedang sebagai variabel bebas adalah jenis rumah sakit dan kelas perawatan, serta karakteristik responden sebagai variabel kontrol.

Analisis data pada penelitian ini dilakukan dalam 2 tahap yaitu analisis data kuantitatif (analisis univariat, bivariat dan multivariat) dilanjutkan analisis data kualitatif. Analisis bivariat dilakukan dengan tabulasi silang antara variabel bebas dan variabel terikat untuk mencari hubungan antar variabel menggunakan chi-square $\left(\chi^{2}\right)$ dengan tingkat kemaknaan $p$ value $<0,05$ dan confidence interval (CI) 95\%, dilanjutkan analisis multivariat menggunakan regresi logistik dengan melihat nilai Odds Ratio (OR) dengan Confidence Interval (CI) 95\%. Kemudian dilanjutkan dengan analisis data kualitatif dengan menelaah seluruh data yang terkumpul dari wawancara mendalam yang dituangkan dalam bentuk narasi (transkrip), kemudian dilakukan koding atau reduksi data dengan melihat panduan pertanyaan wawancara mendalam, untuk dikelompokkan dan dilakukan interprestasi dan konfirmasi.

\section{HASIL DAN PEMBAHASAN}

\section{A. Hasil Penelitian}

1. Karakteristik Responden

a. Responden Kuantitatif

Penelitian

Subyek pada penelitian kuantitatif ini adalah semua pasien penderita 
stroke yang menjalani rawat inap di RS Lestari Raharja dan RSUD Muntilan mulai 15 Februari sampai 30
Mei 2016. Jumlah subyek yang diamati dalam penelitian kuantitatif ini adalah 105 orang.

Tabel 1. Karakteristik Subyek Penelitian Kuantitatif.

\begin{tabular}{|c|c|c|c|c|}
\hline \multirow[t]{2}{*}{ Karakteristik } & \multicolumn{2}{|c|}{$\begin{array}{c}\text { Responden } \\
\text { RS Lestari Raharja }\end{array}$} & \multicolumn{2}{|c|}{$\begin{array}{c}\text { Responden } \\
\text { RSUD Muntilan }\end{array}$} \\
\hline & $n=31$ & $\%$ & $\mathrm{n}=74$ & $\%$ \\
\hline \multicolumn{5}{|l|}{ Umur dalam tahun } \\
\hline$\leq 50$ & 14 & 45,2 & 29 & 60,8 \\
\hline$>50$ & 17 & 54,8 & 45 & 59,5 \\
\hline \multicolumn{5}{|l|}{ Jenis Kelamin } \\
\hline Laki-laki & 14 & 45,2 & 32 & 43,2 \\
\hline Perempuan & 17 & 54,8 & 42 & 56,8 \\
\hline \multicolumn{5}{|l|}{ Pendidikan } \\
\hline Dasar (SD-SMP) & 12 & 38,7 & 50 & 67,6 \\
\hline Menengah (SMA) & 14 & 45,2 & 21 & 28,4 \\
\hline Tinggi (Akademi-PT) & 5 & 16,1 & 3 & 4,1 \\
\hline \multicolumn{5}{|l|}{ Pekerjaan } \\
\hline Bekerja & 21 & 67,7 & 64 & 86,5 \\
\hline Tidak bekerja & 10 & 32,3 & 10 & 13,5 \\
\hline \multicolumn{5}{|l|}{ Kelas Perawatan } \\
\hline Kelas 1-2 & 21 & 67,7 & 9 & 12,2 \\
\hline Kelas 3 & 10 & 32,3 & 65 & 87,8 \\
\hline
\end{tabular}

Karakteristik jenis kelamin responden, sebagian besar responden adalah perempuan $(54,8 \%$ responden di RS Lestari Raharja dan 56,8\% di RSUD Muntilan). Berdasarkan tingkat pendidikan responden di RS Lestari Raharja sebagian besar adalah pendidikan menengah (SMA). Karakteristik pekerjaan responden adalah lebih dari 50\% adalah bekerja. Karakteristik pasien berdasarkan kelas perawatan menunjukkan perbedaan antara kedua rumah sakit, dimana sebagian besar responden dari RS Lestari Raharja dirawat di kelas 12 (67,7\%), sedang responden dari RSUD Muntilan sebagian besar dirawat di kelas $3(87,8 \%)$.

\section{b. Responden Penelitian Kualitatif}

Responden pada penelitian kualitatif diambil dari responden penelitian kuantitatif dari RSUD Muntilan dan RS Lestari Raharja, yang masing masing mewakili responden yang merasa puas dan merasa tidak puas. Wawancara mendalam dilakukan kepada pasien atau keluarga pasien sebagai responden yang mendapatkan pelayanan rumah sakit. Saturasi data atau kejenuhan atas jawaban responden terjadi setelah dilakukan wawancara terhadap 6 responden (Tabel 2). 
Tabel 2. Karakteristik subyek penelitian kualitatif.

\begin{tabular}{cccccc}
\hline Responden & $\begin{array}{c}\text { Jenis } \\
\text { kelamin }\end{array}$ & $\begin{array}{c}\text { Umur } \\
\text { (tahun) }\end{array}$ & $\begin{array}{c}\text { Pendid } \\
\text { ikan }\end{array}$ & Rumah Sakit & $\begin{array}{c}\text { Kelas } \\
\text { perawatan }\end{array}$ \\
\hline R1 & Perempuan & 45 & SD & RS Lestari Raharja & Kelas 3 \\
R2 & Perempuan & 24 & SLTA & RS Lestari Raharja & Kelas 1 \\
R3 & Laki-laki & 50 & SLTA & RS Lestari Raharja & Kelas 1 \\
R4 & Laki-laki & 56 & SMP & RSUD Muntilan & Kelas 3 \\
R5 & Perempuan & 47 & SMP & RSUD Muntilan & Kelas 3 \\
R6 & Laki-laki & 28 & PT & RSUD Muntilan & Kelas 2 \\
\hline
\end{tabular}

\section{Kepuasan pasien penderita} stroke

Pembuatan kategori kepuasan total pasien, dilakukan setelah dianalisis terhadap 26 item pertanyaan dengan nilai median 78 , sehingga pembuatan kategori kepuasan sebagai berikut:

(1) Puas, $x \geq 78$

(2) Tidak puas, $x<78$

Tabel 3 menunjukkan bahwa sebagian besar responden merasa puas terhadap pelayanan rumah sakit $(80,0 \%)$.

Tabel 3. Kepuasan Pasien Stroke Terhadap Pelayanan Rumah Sakit.

\begin{tabular}{|c|c|c|}
\hline Kepuasan Pasien & $\mathbf{n}$ & $\%$ \\
\hline Puas & 84 & 80,00 \\
\hline Tidak puas & 21 & 20,00 \\
\hline Total & 105 & 100,00 \\
\hline
\end{tabular}

Kepuasan pasien dilihat dari aspeknya menunjukkan bahwa aspek bukti fisik, daya tanggap, jaminan dan empati, lebih dari $85 \%$ responden menyatakan puas, sedangkan aspek keandalan $17,1 \%$ responden merasa tidak puas (Tabel 4).

Tabel 4. Kepuasan Pasien Stroke Berdasarkan Aspek Kepuasan.

\begin{tabular}{lcc}
\hline Aspek-aspek kepuasan & Puas (\%) & Tidak puas (\%) \\
\hline Aspek bukti fisik & 88,6 & 11,4 \\
Aspek keandalan & 82,9 & 17,1 \\
Aspek daya tanggap & 88,6 & 11,4 \\
Aspek jaminan & 87,6 & 12,4 \\
Aspek empati & 89,5 & 10,5 \\
\hline
\end{tabular}

\section{Analisis hubungan antara karakteristik subyek terhadap kepuasan pasien}

Tabel 5 menunjukkan bahwa setelah dilakukan analisis bivariat, karakteristik responden yang secara statistik mempunyai hubungan signifikan dengan kepuasan pasien adalah jenis kelamin. Pasien laki-laki merasakan kepuasan 4,25 kali lebih besar dibandingkan dengan pasien perempuan. 
Tabel 5. Hubungan Karakteristik Subyek Terhadap Kepuasan Pasien Rumah Sakit.

\begin{tabular}{|c|c|c|c|c|c|c|c|}
\hline \multirow{3}{*}{ Variabel } & \multicolumn{4}{|c|}{ Kepuasan } & \multirow{3}{*}{ OR } & \multirow{3}{*}{$95 \% \mathrm{CI}$} & \multirow{3}{*}{$\underset{\text { value }}{p}$} \\
\hline & \multicolumn{2}{|c|}{ Puas } & \multicolumn{2}{|c|}{ Tidak } & & & \\
\hline & $\mathbf{n}$ & $(\%)$ & $\mathbf{n}$ & $(\%)$ & & & \\
\hline \multicolumn{8}{|c|}{ Karakteristik Subyek } \\
\hline \multicolumn{8}{|l|}{ Umur pasien } \\
\hline$>50$ tahun & 49 & $(79,0)$ & 13 & $(21,0)$ & 0,86 & $0,27-2,53$ & 0,76 \\
\hline$\leq 50$ tahun(R) & 35 & $(81,4)$ & 8 & $(16,6)$ & & & \\
\hline \multicolumn{8}{|l|}{ Jenis kelamin } \\
\hline Laki-laki & 42 & $(91,3)$ & 4 & $(8,7)$ & 4,25 & $1,22-18,59$ & $0,01^{*}$ \\
\hline Perempuan(R) & 42 & $(71,2)$ & 17 & $(28,8)$ & & & \\
\hline \multicolumn{8}{|l|}{ Pendidikan } \\
\hline SD-SMP(R) & 48 & $(77,4)$ & 14 & $(22,6)$ & & & \\
\hline SLTA & 28 & $(80,0)$ & 7 & $(20,0)$ & 1,16 & $0,38-3,83$ & 0,76 \\
\hline $\mathrm{D} 3 / \mathrm{PT}$ & 8 & $(100,0)$ & 0 & $(0,0)$ & - & - & - \\
\hline \multicolumn{8}{|l|}{ Pekerjaan } \\
\hline Bekerja & 70 & $(82,3)$ & 15 & $(17,7)$ & 2,00 & $0,53-6,70$ & 0,21 \\
\hline Tidak & 14 & $(70,0)$ & 6 & $(30,0)$ & & & \\
\hline
\end{tabular}

Keterangan:

$(\mathrm{R})=$ Reference

$*=\mathrm{p}<0.05$

4. Analisis

variabel

kepuasan pasien

\section{hubungan \\ bebas}

Tabel 6 menunjukkan bahwa $82,4 \%$ pasien yang dirawat di RSUD Muntilan dan $74,2 \%$ di RS Lestari
Raharja menyatakan puas terhadap pelayanan rumah sakit. Tidak ada perbedaan kepuasan pasien yang dirawat di RSUD Muntilan dibanding dengan pasien yang dirawat di RS Lestari Raharja.

Tabel 6. Hubungan Jenis Rumah Sakit Terhadap Kepuasan Pasien Rumah Sakit.

\section{Kepuasan}

\begin{tabular}{|c|c|c|c|c|c|c|c|}
\hline \multirow[t]{2}{*}{ Variabel } & \multicolumn{2}{|c|}{ Puas } & \multicolumn{2}{|c|}{ Tidak } & \multirow[t]{2}{*}{ OR } & \multirow[t]{2}{*}{$95 \% \mathrm{CI}$} & \multirow{2}{*}{$\underset{\text { value }}{p}$} \\
\hline & $\mathbf{n}$ & $(\%)$ & $\mathbf{n}$ & $(\%)$ & & & \\
\hline \multicolumn{8}{|c|}{ Jenis Rumah sakit } \\
\hline Pemerintah & 61 & $(82,4)$ & 13 & $(17,6)$ & 1,63 & $0,51-4,90$ & 0,33 \\
\hline Swasta(R) & 23 & $(74,2)$ & 8 & $(25,8)$ & & & \\
\hline
\end{tabular}

Keterangan:

$(\mathrm{R})=$ Reference

$*=\mathrm{p}<0.05$

Analisis bivariat untuk melihat hubungan kelas perawatan terhadap kepuasan pasien menunjukkan $70 \%$ pasien yang dirawat di kelas 1 dan 2 serta $84 \%$ pasien di kelas 3 menyatakan puas terhadap pelayanan rumah sakit. Pasien yang dirawat di kelas 1 dan 2 merasa lebih puas terhadap pelayanan rumah sakit 0,44 kali lebih besar dibandingkan pasien yang dirawat di kelas $3(O R \quad 0,44)$ (Tabel 7). 
Tabel 7. Hubungan Kelas Perawatan Terhadap Kepuasan Pasien Rumah Sakit.

\begin{tabular}{lccccccc}
\hline \multirow{2}{*}{ Variabel } & \multicolumn{9}{c}{ Puas } & \multicolumn{2}{c}{ Tidak Puas } & OR & $\mathbf{9 5 \% C I}$ & p value \\
& $\mathbf{N}$ & $\mathbf{( \% )}$ & $\mathbf{n}$ & $\mathbf{( \% )}$ & & & \\
\hline Kelas Perawatan & & & & & & & \\
1-2 & 21 & $(70,0)$ & 9 & $(30,0)$ & 0,44 & $0,14-1,38$ & 0,10 \\
$3(\mathrm{R})$ & 63 & $(84,0)$ & 12 & $(16,0)$ & & & \\
\hline
\end{tabular}

Keterangan:

$(\mathrm{R})=$ Reference

$*=\mathrm{p}<0.05$

Pada analisis multivariat pengaruh jenis rumah sakit terhadap kepuasan pasien tanpa kontribusi dari variabel confonding didapatkan hasil OR $(1,04)$, 95\%CI $(0,30-3,59)$ dan $p$ value $(0,94)$ serta pengaruh kelas perawatan terhadap kepuasan pasien

didapatkan hasil OR $(0,45), 95 \% C I$ $(0,13-1,53)$ dan $p$ value $(0,20)$. Analisis ini menghasilkan angka $\mathrm{R}^{2}$ hanya 2 $\%$, artinya pengaruh variabel jenis rumah sakit dan kelas perawatan secara bersamaan terhadap kepuasan pasien sebesar $2 \%$ (Tabel 8).

Tabel 8. Analisis Multivariat Jenis Rumah Sakit dan Kelas Perawatan Terhadap Kepuasan Pasien Tanpa Kontribusi Dari Variabel Confonding.

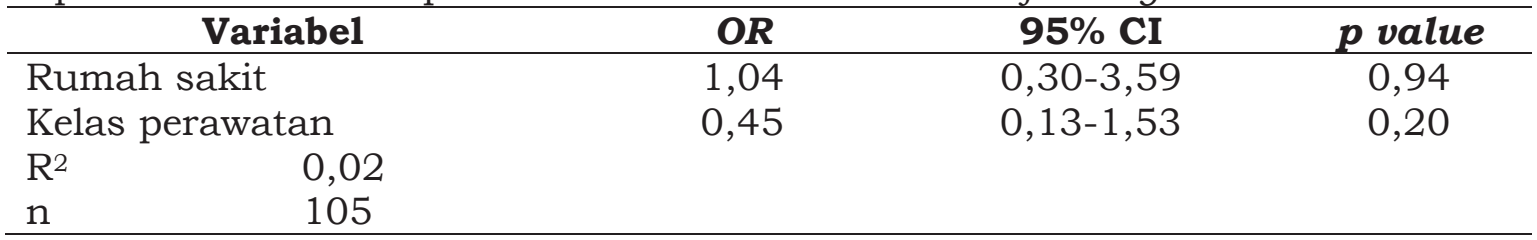

Keterangan:

$(\mathrm{R})=$ Reference

$*=\mathrm{p}<0.05$

Pada analisis multivariat pengaruh jenis rumah sakit terhadap kepuasan pasien dengan kontribusi dari variabel confonding didapatkan hasil OR $(1,38), 95 \% C I \quad(0,36-5,28)$ serta $p$ value $(0,63)$, dan pengaruh kelas perawatan terhadap kepuasan pasien dengan kontribusi dari variabel confonding didapatkan hasil $O R$

$(0,69), 95 \% C I(0,18-2,62)$ serta $p$ value $(0,59)$. Dari analisis multivariat ini, terdapat peningkatan $\mathrm{R}^{2}$ sebesar $6 \%$, artinya variabel jenis kelamin memberikan kontribusi terhadap kepuasan sebesar $6 \%$. Secara keseluruhan pengaruh dari variabel bebas dan jenis kelamin terhadap kepuasan sebesar 8\% (Tabel 9).

Tabel 9. Analisis Multivariat Jenis Rumah Sakit dan Kelas Perawatan Terhadap Kepuasan Pasien Dengan Kontribusi Dari Variabel Confonding.

\begin{tabular}{|c|c|c|c|c|}
\hline Variabe & & OR & $95 \% \mathrm{CI}$ & $p$ value \\
\hline Rumah sakit & & 1,04 & $0,30-3,59$ & 0,94 \\
\hline Kelas perawatan & & 0,69 & $0,18-2,62$ & 0,59 \\
\hline Jenis kelamin & & 4,01 & $1,19-13,43$ & 0,03 \\
\hline $\mathrm{R}^{2}$ & 0,08 & & & \\
\hline $\mathrm{n}$ & 105 & & & \\
\hline
\end{tabular}

Keterangan:

$(\mathrm{R})=$ Reference

$*=\mathrm{p}<0.05$ 


\section{B. Pembahasan}

\section{Kepuasan pasien stroke terhadap rumah sakit}

Jumlah sampel pada penelitian ini adalah 105 responden. Jumlah sampel minimal menurut teori Gay, yang menyatakan bahwa ukuran sampel yang dapat diterima berdasarkan desain penelitian yang digunakan untuk populasi yang relatif kecil adalah jumlah sampel minimal $20 \%$ dari jumlah populasi (49 orang). ${ }^{13}$ Hasil penelitian terhadap 105 responden menunjukan bahwa $80 \%$ responden menyatakan puas terhadap pelayanan rumah sakit. Hasil pengukuran kepuasan pasien ditinjau dari aspek kepuasan dalam penelitian ini berturut-turut sebagai berikut; aspek empati 89,5\%, aspek bukti fisik dan daya tanggap 88,6\%, aspek jaminan $87,6 \%$ serta aspek keandalan $82,9 \%$. Hal ini juga dapat dilihat dari hasil wawancara sebagai berikut:

"Pelayanan dokter dan perawat baik kok, suka menyapa pasien, tapi yaitu ruangannya panas, apalagi ruang tunggunya, semoga kedepan lebih ditata"

"Puas, nyaman tapi air kamar mandinya sedikit keruh dan kebersihannya agak kurang, bagian kolong-kolong kurang dibersihkan,..., kalau ke rumah sakit agak siang, ..parkirnya sulit sekali ......."

Penelitian sebelumnya di Manado tahun 2015, disimpulkan bahwa terdapat hubungan antara dimensi bukti fisik, keandalan, daya tanggap, jaminan, dan empati dengan kepuasan pasien. Daya tanggap merupakan dimensi yang paling dominan pengaruhnya terhadap kepuasan pasien di poliklinik Penyakit Dalam RSUP Prof.
Dr. R. D. Kandou Manado. ${ }^{14}$ Penelitian lain tentang kepuasan pasien di Dindigul India, yang dilakukan terhadap pasien rawat inap menunjukan 49\% kualitas layanan baik, hasil sebaliknya ditunjukkan penelitian di Madagaskar yang dilakukan 2009 menunjukkan 82,7\% pasien puas terhadap pelayanan dokter ${ }^{15}$. Data tersebut menunjukkan bahwa sebagian besar pasien merasa puas dengan pelayanan rumah sakit, walaupun terdapat perbedaan dari besar kecilnya aspek kepuasan yang dirasakan. Kepuasan pasien secara umum yang ditunjukkan pada penelitan ini hampir sama dengan penelitian sebelumnya, disebabkan kedua rumah sakit telah menerapkan standard operating procedure dan clinical pathway yang sama. Perbedaan hasil aspek kepuasan tersebut disebabkan karena kepuasan pasien sangat dipengaruhi oleh banyak faktor. Hal ini juga terlihat pada hasil wawancara dengan responden tentang kepuasan, bahwa fasilitas fisik, sikap petugas kesehatan, kemampuan dan ketrampilan petugas, komunikasi dengan keluarga pasien serta penghargaan kepada pasien merupakan hal yang dibutuhkan dalam keberhasilan pelayanan kesehatan sehingga memunculkan kepuasan, seperti yang disampaikan sebagai berikut:

"Harapan saya terus mempertahankan keramahan dan ketanggapan penanganan pada pasien dan keluarganya, terutama kita kita diajak rembugan saat ada tindakan atau obat yang harus tambah biaya ya, jadi tidak kaget saat dikasih tahu, serta kebersihan lingkungan harus ditingkatkan"

"Melayani dengan tulus dan sepenuh hati sehingga pasien merasa nyaman, terutama kalau 
periksa lewat poliklinik, kalau bisa dipercepat daftarnya kan pasien kesakitan, kadang-kadang banyak pertanyaan saat daftar itu, waduh, apa ndak bissa ya pasien diperiksa dulu urusan tanya kartu dan lainnya itu belakangan"

\section{Hubungan antara variabel bebas dan pengganggu terhadap kepuasan pasien}

Variabel pengganggu yang menunjukkan hasil signifikan secara statistik pada analisa bivariat adalah jenis kelamin, $p$ value pada karakteristik ini adalah 0,01 yang berarti ada hubungan yang bermakna antara karakteristik jenis kelamin dengan kepuasan pasien dan diperoleh hasil OR 4,25 sehingga dapat diartikan bahwa pasien laki-laki merasakan kepuasan 4,25 kali lebih besar dibandingkan dengan pasien perempuan.

Oroh, et al. melakukan penelitian pada tahun 2014 di RSUD Noongan yang menyimpulkan bahwa responden laki-laki menyatakan puas dengan pelayanan keperawatan $(87,2 \%)$, dengan uji chi-square diperoleh $p$ value 0,05 , sehingga dapat diambil kesimpulan ada hubungan yang bermakna antara jenis kelamin dengan tingkat kepuasan pasien rawat inap. ${ }^{16}$

Kesamaan hasil penelitian sebelumnya dengan penelitian ini disebabkan karena jenis kelamin memiliki pengaruh terhadap pandangan tentang jasa yang diberikan. Perempuan lebih banyak melihat penampilan secara detail, sedangkan laki-laki tidak memperhatikan hal tersebut. ${ }^{17}$

Analisa bivariat untuk melihat hubungan variabel jenis rumah sakit terhadap kepuasan pasien, didapatkan hasil $82,4 \%$ pasien yang dirawat di RSUD Muntilan dan 74,2\% di RS Lestari Raharja menyatakan puas terhadap pelayanan rumah sakit. Hal tersebut sesuai dengan adanya perbedaan kelas kedua rumah sakit, RSUD Muntilan yang merupakan rumah sakit kelas C mempunyai fasilitas yang lebih lengkap. Responden yang menyatakan puas terhadap bukti fisik di RSUD Muntilan Kabupaten Magelang $(89,2 \%)$ lebih besar dibandingkan di RS Lestari Raharja (87,1\%). Karim dalam penelitian tentang kepuasan pasien menggunakan metode HCAHPS (The Hospital Consumer Assessment Healthcare Providers and System) di Yogjakarta tahun 2014, menyimpulkan tidak terdapat perbedaan tingkat kepuasan pasien di rumah sakit swasta dan rumah sakit negeri di Jogjakarta, dengan angka signifikansi $p$ value $0,591 .{ }^{18}$

Uji statistik hubungan kelas perawatan dengan kepuasan pasien menunjukkan, $70 \%$ pasien yang dirawat di kelas 1 dan 2 serta $84 \%$ pasien kelas 3 menyatakan puas terhadap pelayanan rumah sakit. Penelitian sebelumnya yang mendukung hasil penelitian ini, Tecualu, et al. dalam penelitiannya di Jakarta Barat pada tahun 2007 menyebutkan tidak ada hubungan yang signifikan antara kelas perawatan terhadap kepuasaan pasien yang di rawat di rumah sakit pemerintah dan swasta. ${ }^{19}$ Oroh, et al. melakukan penelitian di RSUD Noongan menyimpulkan tidak ada hubungan yang bermakna antara kelas perawatan dengan kepuasan pasien. ${ }^{16}$

\section{Pengaruh jenis rumah sakit dan kelas perawatan terhadap kepuasan pasien.}

Hasil analisis regresi logistik pengaruh jenis rumah sakit terhadap kepuasan pasien tanpa kontribusi dari variabel jenis kelamin didapatkan hasil OR $(1,04), 95 \% C I(0,30-3,59)$ dan $p$ value $(0,94)$, sedang pengaruh kelas perawatan terhadap kepuasan pasien tanpa kontribusi dari variabel jenis 
kelamin didapatkan hasil OR $(0,45)$, $95 \% C I(0,13-1,53)$ dan $p$ value $(0,20)$. Kesimpulan yang dapat ditarik dari analisis diatas adalah tidak ada hubungan yang signifikan dari 2 variabel bebas tersebut terhadap kepuasan pasien. Analisis ini menghasilkan angka $\mathrm{R}^{2}$ hanya $2 \%$, artinya pengaruh variabel rumah sakit dan kelas perawatan secara bersamaan terhadap kepuasan pasien sebesar $2 \%$.

Pada analisis multivariat pengaruh jenis rumah sakit terhadap kepuasan pasien dengan melihat kontribusi dari variabel jenis kelamin didapatkan hasil OR $(1,38), 95 \% C I$ $(0,36-5,28)$ serta $p$ value $(0,63)$ dan pengaruh kelas perawatan terhadap kepuasan pasien didapatkan hasil $O R$ $(0,69), 95 \% C I(0,18-2,62)$ serta $p$ value $(0,59)$. Dari hasil analisis tersebut diketahui tetap tidak ada hubungan yang signifikan antara variabel bebas terhadap variabel terikat.

Pengaruh variabel confonding yaitu jenis kelamin terhadap kepuasan pasien setelah dilakukan analisis regresi logistik menunjukkan hasil yang tetap signifikan yaitu $O R$ $(4,01), 95 \% C I(1,19-13,43)$ dan $p$ value $(0,03)$ sehingga secara statistik jenis kelamin mempunyai pengaruh yang signifikan terhadap kepuasan pasien, dengan peningkatan nilai $\mathrm{R}^{2}$ sebesar $6 \%$, artinya variabel jenis kelamin memberikan kontribusi terhadap kepuasan sebesar 6\%. Secara keseluruhan pengaruh dari variabel bebas dan jenis kelamin terhadap kepuasan sebesar $8 \%$.

\section{KESIMPULAN}

1. Kepuasan pasien stroke peserta JKN yang dirawat di RS Lestari Raharja dan RSUD Muntilan tidak ada berbeda.

2. Tidak ada hubungan antara kelas perawatan dan kepuasan pasien stroke peserta JKN yang dirawat di RS Lestari Raharja dan RSUD Muntilan Kabupaten Magelang.

\section{DAFTAR PUSTAKA}

1. American Heart Association. Heart disease \& stroke statistics: Our guide to current statistics and the supplement to our heart \& stroke facts. 2009.

2. Kementerian Kesehatan RI, Badan Penelitian dan Pengembangan Kesehatan. Riset Kesehatan Dasar 2013. 2013.

3. Pinzon RT, Adnyana KS, Sanyasi RD. Profil epidemiologi stroke: Gambaran tentang pola demografi, faktor resiko, gejala klinik dan luaran pasien stroke. Yogyakarta: Betha Grafika Yogyakarta. 2016.

4. Pinzon RT, Asanti L, Widyo K. Clinical pathway dalam pelayanan stroke akut: Apakah pathway memperbaiki proses pelayanan?. Jurnal Manajemen Pelayanan Kesehatan. Mar 1: 12: 20-4. 2009.

5. Mishra PH, Gupta S. Study of patient satisfaction in a surgical unit of a tertiary care teaching hospital. Clinical Orthopaedics and Trauma J. 3(1): 43-5. 2012.

6. Kim J, Han W. Improving service quality in long-term care hospitals: National evaluation on long-term care hospitals and employees perception of quality dimensions. Osong Public Health and Research Perspectives. 3(2): 94-5. 2012.

7. Suryawati C, Dharminto, Shaluhiyah Z. Penyusunan indikator kepuasan pasien rawat inap rumah sakit di Provinsi Jawa Tengah. Jurnal Manajemen Pelayanan Kesehatan. Des 4: 9: 177-8. 2006.

8. Andaleeb SS. Service quality perceptions and patient satisfaction: A study of hospitals in a developing country. Social 
Science \& Medicine. 52(9): 135970. 2001.

9. Al Khattab S, Aborumman AH. Healthcare service quality: Comparing public and private hospitals in Jordan. International Business Management. 5(5): 2478. 2011.

10. Davis K, Collins KS, Schoen C, et al. Choice matters: Enrollees' views of their health plans. Health Affairs. 14(2): 99-13. 1995.

11. Neumann M, Bensing J, Wirtz M, et al. The impact of financial incentives on physician empathy: A study from the perspective of patients with private and statutory health insurance. Patient Education and Counseling: 84(2): 208-16. 2011.

12. Creswell JW, Plano Clark V L. Mixed Methods Research. 2007

13. Umar H. Metode Penelitian untuk skripsi dan tesis bisnis. 2011

14. Mumu LJ, Kandou GD, Doda DV. Analisis faktor-faktor yang berhubungan dengan kepuasan pasien di poliklinik penyakit dalam RSUP Prof. Dr. R. D. Kandou Manado. JMPK Universitas Sam Ratulangi Manado. 2015

15. Glick P. How reliable are surveys of client satisfaction with healthcare services? Evidence from matched facility and household data in Madagascar. Social Science \& Medicine. 68(2): 368-79. 2009.

16. Oroh ME, Rompas S, Pondaag L. Faktor-faktor yang berhubungan dengan tingkat kepuasan pasien rawat inap terhadap pelayanan keperawatan di ruang interna RSUD Noongan. Jurrnal Keperawatan, Ejournal Universitas Sam Ratulangi Manado. 2014.

17. Gunarsa SD. Psikologi keperawatan. Jakarta. 2008.

18. Karim FM. Perbedaan tingkat kepuasan pasien menggunakan metode HCAHPS di rumah sakit swasta dan rumah sakit negeri di DIY. Tesis. Universitas Muhammadiyah Yogyakarta. 2014.

19. Tecualu M, Kristaung R, Iskandar TD. Pengaruh kelas perawatan, penanggung biaya dan pemulihan pelayanan terhadap kepuasan pasien pada rumah sakit pemerintah dan swasta di Jakarta Barat. Jurnal Kompetensi Manajemen Bisnis. Jan: 1(2): 11023. 2017. 